\title{
Current Perspectives on Neurostimulation for the Management of Chronic Low Back Pain: A Narrative Review
}

This article was published in the following Dove Press journal: Journal of Pain Research

\author{
David A Provenzano (iD ${ }^{1,2}$ \\ Jared A Heller $\mathbb{D}^{3}$ \\ Michael $C$ Hanes ${ }^{4}$ \\ 'Pain Diagnostics and Interventional \\ Care, Sewickley, PA, USA; ${ }^{2}$ Western PA \\ Surgery Center, Wexford, PA, USA; \\ ${ }^{3}$ Washington \& Jefferson College, \\ Washington, PA, USA; ${ }^{4}$ ax Spine \& Pain \\ Centers, Jacksonville, FL, USA
}

\begin{abstract}
Neurostimulation techniques for the treatment of chronic low back pain (LBP) have been rapidly evolving; however, questions remain as to which modalities provide the most efficacious and durable treatment for intractable axial symptoms. Modalities of spinal cord stimulation, such as traditional low-frequency paresthesia based, high-density or high dose (HD), burst, 10-kHz high-frequency therapy, closed-loop, and differential target multiplexed, have been limitedly studied to determine their efficacy for the treatment of axial LBP. In addition, stimulation methods that target regions other than the spinal cord, such as medial branch nerve stimulation of the multifidus muscles and the dorsal root ganglion may also be viable treatment options. Here, current scientific evidence behind neurostimulation techniques have been reviewed with a focus on the management of chronic axial LBP.
\end{abstract}

Keywords: spinal cord stimulation, chronic, axial, neuromodulation

\section{Introduction}

Approximately one in five adults suffer from chronic low back pain (LBP) with over 575 million individuals suffering worldwide. ${ }^{1-3}$ Chronic LBP is associated with significant direct health-care costs including physical therapy, inpatient services, prescription medications, and interventional care, as well as indirect costs including lost work productivity. ${ }^{4}$

When discussing chronic LBP, it is important to provide a contextual definition. In reference to time, chronic back pain is typically defined as pain lasting longer than 12 weeks or beyond the expected period of healing. ${ }^{5}$ A well-defined underlying pathological cause may not always be identified. As defined by NASS (North American Spine Society), chronic LBP is "pain of musculoskeletal origin extending from the lowest rib to the gluteal fold that may at times extend as somatic referred pain into the thigh." Chronic pain that is localized in the lower back is considered axial LBP, while pain that radiates past the buttock and down the $\operatorname{leg}(\mathrm{s})$ is classified as radicular pain. Pain that chronically occurs concurrently in the back and the leg is considered back and leg pain. Further classifications can be subdivided into individuals that have chronic LBP following back surgery (eg postlaminectomy pain syndrome; PLPS) and those that have nonsurgical refractory LBP.
Correspondence: David A Provenzano 30I Ohio River Blvd Suite 203, PA, I5I43, USA

Tel + | 4I $2-22 \mid-7640$

Fax + I 4I2-490-7640

Email davidprovenzano@hotmail.com 
Unfortunately, the treatment of chronic LBP can be challenging and refractory to many interventions. Forms of neuromodulation, such as spinal cord stimulation (SCS), have been utilized over the last 50 years to assist in the treatment of intractable LBP often with a radicular component. Since the first SCS unit was implemented in a clinical setting by Shealy, SCS has been growing in popularity as its clinical safety, cost utility, and efficacy increase..$^{7-9}$ Spinal cord stimulation is now a widely accepted form of therapy for chronic intractable neuropathic pain and is the most commonly employed neurostimulation therapy for the treatment of chronic pain. More specifically, SCS has been used extensively for the treatment of PLPS (approximately $70 \%$ of all implants); however, it has not yet been fully investigated as a treatment modality for patients who have not previously undergone back surgery. ${ }^{10,11}$ When treating PLPS, SCS has traditionally been used to target radicular symptoms, but at times lacks effective prolonged coverage of axial LBP symptoms. ${ }^{11,12}$

The use of neurostimulation for the treatment of chronic LBP has been met with mixed results. Due to a multitude of recent technological and hardware advancements, including programming (eg novel waveform patterns and alterations in programming parameters and energy delivery), new neural targets, and improved lead placement; neurostimulation has improved in its ability to treat axial LBP. ${ }^{1,13-15}$ Here, we will provide an up-to-date narrative review of the scientific evidence of neurostimulation therapies with a focus on the management of chronic axial LBP.

\section{Traditional Low-frequency Paresthesia-based SCS}

Traditional low-frequency (ie frequency $\leq 1000 \mathrm{~Hz}$ ) paresthesia based SCS has been shown to be clinically effective for many pain conditions including PLPS. However, the ability of SCS to successfully manage chronic axial LBP has been associated with mixed results and limited efficacy; often with declining efficacy over time. ${ }^{8,16}$ A recent systematic review utilizing the Cochrane risk of bias tool and GRADE system demonstrated very low quality evidence for lowfrequency SCS for the treatment of axial LBP with concomitant leg pain. ${ }^{16}$ The North American Spine
Society (NASS) recently published evidence-based clinical guidelines for multidisciplinary spine care for the treatment of LBP which determined that there was insufficient evidence to make a recommendation for or against the use of SCS for the treatment of LBP. ${ }^{6}$ However, it must be pointed out that new SCS research has been published that was not included in this NASS review. In addition, recent attention has been placed on SCS explant rates with a major driver being loss of clinical efficacy. ${ }^{17-20}$ Therefore, it is prudent for physicians and manufacturers to understand the current level of evidence for SCS treatment of chronic axial LBP and to continue SCS advancement prior to large-scale clinical utilization for this indication.

When evaluating the ability of traditional lowfrequency SCS to effectively treat lumbar spine conditions, five randomized controlled trials (RCTs; Table 1) are available that include a traditional low-frequency study arm. ${ }^{13,14,21-24}$ These studies all included patients with axial LBP and leg pain. Three of the five studies provide information specifically on back pain reduction with the traditional low-frequency SCS as a secondary outcome. ${ }^{13,22,24}$ The earliest RCT by Kumar et $\mathrm{al}^{12,24}$ evaluating SCS LBP reduction as a secondary outcome demonstrated a significant VAS reduction at six months within the SCS group and between the SCS group and conventional medical management. However, by 24 months the between group difference for axial LBP was absent. The two most recent RCTs providing information on the treatment of axial LBP have demonstrated positive sustained results at 12 months, and in one study at 24 months. In the Kapural et al study $^{14}$ the traditional SCS arm demonstrated a significant sustained $44 \%$ LBP reduction at 24 months. In the Mekhail et al study, ${ }^{22}$ the traditional SCS arm demonstrated a 54\% reduction in LBP at 12 months. In addition to the RCTs, nonrandomized comparative studies and prospective cohort studies have suggested a positive reduction in axial LBP with SCS treatment. ${ }^{16}$ PLPS was a common clinical diagnosis and only two of the five papers specifically included individuals with nonsurgical refractory LBP. Therefore, there is limited insight on the ability of traditional low-frequency paresthesia based SCS to effectively treat nonsurgical refractory LBP. 
Several modifications to traditional low-frequency paresthesia based SCS have been introduced; attempting to improve axial LBP coverage and treatment (Figure 1 and Table 2) ${ }^{15,25}$ The modifications have included attention to stimulation target zones, lead placement, equipment design, programming algorithms, and electrical parameter modifications. ${ }^{26-32}$ Each modification has been suggested to overcome constraints in either clinical, physiological, or anatomical areas. Theorized anatomical constraints have included the close relationship with the dorsal columns to the dorsal root fibers, the increased thickness of the dorsal cerebral spinal fluid at $\mathrm{T} 8-\mathrm{T} 9$, and the size of the L1 and L2 dermatomes with their close proximity to the T12 dermatome. ${ }^{15}$ Increased stimulation in the T12 dermatome may result in unwanted chest wall coverage. ${ }^{33}$ One of the major challenges with traditional low-frequency SCS has been the ability to capture axial LBP with paresthesia coverage. Paresthesia capture was once considered to be of critical importance because initial work demonstrated that superposition of stimulation paresthesias upon a patient's pain topography to be a predictor of successful pain relief. ${ }^{34}$ However, current SCS research has demonstrated that continuous paresthesia coverage is not required for pain relief with specific programs and frequency settings. $^{21,25,35}$

\section{Closed-loop SCS}

Conventional SCS modalities use preset programs with regard to frequency, pulse-width, and amplitude which are used to modulate pain processing (Figure 2). These conventional SCS modalities are open-loop systems which require the operator (eg patient, physician, or device representative) to manually change fixed output stimulator settings. To improve open-loop systems, sensing technology has been employed to alternate between preset programs for specific positions. ${ }^{36}$ Automatic position adaptive stimulation (Figure 2) provides benefits for pain relief, convenience, and a reduction in daily number of amplitude adjustments in comparison to traditional SCS systems (18.2 adjustments per day vs 30.7 adjustments per day). ${ }^{36}$

Although automatic position adaptive stimulation with open-loop systems have been helpful, limitations still exist since integrated feedback from the nervous system is not incorporated into stimulation patterns. Recently, in an effort to overcome this limitation, a closed-loop SCS system has been introduced which monitors the physiologic state of the nervous system and modifies SCS parameters in real time based on this input. ${ }^{37}$ The deployment of a closed-loop system for medical purposes is not new. This technology has been used extensively in the field of cardiology. ${ }^{37}$ Previous challenges with closed-loop systems that have limited clinical neuromodulation introduction have included technology restrictions (eg sensing and stimulation through the same lead), hardware design, programming intricacies, and increased energy requirements due to computational, sensing and stimulation duties. ${ }^{38}$

Learning from previous clinically implemented closedloop systems (Figure 2), the therapeutic effects associated with low-frequency traditional paresthesia-based SCS may be increased. Utilizing a closed-loop SCS system that employed evoked compound action potential (ECAP) sensing, Russo et $\mathrm{al}^{39,40}$ examined the ability to effectively treat individuals with lower back and/or leg pain. For this study, patients were trialed and implanted with a closedloop SCS system with integrated feedback control using ECAPs to provide a measure of the response of nerve fibers to stimulation and to automatically maintain desired dorsal column fiber recruitment levels within the therapeutic window. The system consisted of two 12-contact percutaneous leads. Preliminary results were published for the three- and six-month outcomes. Fifty-seven percent of patients had PLPS and the primary region of pain was the lower back for approximately $72 \%$ of patients. Fortynine patients completed the end of trial assessment and 36 patients elected to move forward to implantation. At six months, $85.7 \%$ of patients reported LBP relief $\geq 50 \%$. Due to its short-term success, the study was continued further to provide 12-month outcomes which were published in $2019 .{ }^{40}$ The 12 -month data demonstrated that $76.9 \%$ of patients reported $\geq 50 \%$ total pain reduction and $56.4 \%$ of patients reported $\geq 80 \%$ LBP reduction; therefore, providing clinical evidence to support the use of the closed-loop SCS system not only for neuropathic radicular pain but also for the treatment of axial LBP. ${ }^{40}$

A multicenter double-blind RCT enrolling 134 patients examining the ability of a closed-loop SCS system to treat chronic back and leg pain further provided evidence of safety and efficacy. ${ }^{22}$ Patients were randomized either to an ECAP controlled closed-loop or fixed output open-loop SCS systems. The baseline demographics demonstrated that $57 \%$ to $61 \%$ of the patients had a diagnosis of PLPS and 58\% to $61 \%$ of the patients had previous back surgery depending on the treatment arm. The primary analysis was at three months and follow-up was continued to 12 months (prespecified analysis). At three months, $82.3 \%$ of the closed-loop SCS 
Table I Randomized Controlled Trials of Traditional SCS for Lumbar Back Pain

\begin{tabular}{|c|c|c|c|c|c|c|c|c|c|}
\hline Author & $\begin{array}{l}\text { Type of } \\
\text { Study }\end{array}$ & $\begin{array}{l}\text { Number } \\
\text { of Trial } \\
\text { Patients n }\end{array}$ & $\begin{array}{l}\text { Successful } \\
\text { Trials }\end{array}$ & $\begin{array}{l}\text { Trial } \\
\text { Patients } \\
\text { Progressing } \\
\text { to Implant }\end{array}$ & $\begin{array}{l}\text { Patients } \\
\text { with } \\
\text { PLPS }\end{array}$ & $\begin{array}{l}\text { Patients } \\
\text { without } \\
\text { Previous } \\
\text { Back } \\
\text { Surgery }\end{array}$ & $\begin{array}{l}\text { Range of } \\
\text { Follow- } \\
\text { Up }\end{array}$ & $\begin{array}{l}\text { Pain } \\
\text { Pattern }\end{array}$ & $\begin{array}{l}\text { Pertinent } \\
\text { Inclusion } \\
\text { and } \\
\text { Exclusion } \\
\text { Criteria }\end{array}$ \\
\hline $\begin{array}{l}\text { Kumar et al } \\
2007^{24} \text { and } \\
2008^{12}\end{array}$ & $\begin{array}{l}\text { Traditional } \\
\text { vs CMM }\end{array}$ & 100 & Traditional: 83\% & $89 \%$ & $100 \%$ & $0 \%$ & $\begin{array}{l}6-24 \\
\text { months }\end{array}$ & $\begin{array}{l}\text { Radicular } \\
>\text { axial }\end{array}$ & $\begin{array}{l}\text { Inclusion: PLPS; } \\
\text { predominant leg pain. } \\
\text { Exclusion: predominant } \\
\text { back pain. }\end{array}$ \\
\hline $\begin{array}{l}\text { Kapural et al } \\
2015^{13} \text { and } \\
2016^{14}\end{array}$ & $\begin{array}{l}\text { Traditional } \\
\text { vs } 10-\mathrm{kHz} \\
\mathrm{HF}\end{array}$ & 198 & $\begin{array}{l}\text { Overall: } 90 \% \\
\text { I0-kHz HF: } 93 \% \\
\text { Traditional: } 88 \%\end{array}$ & $86 \%$ & $77 \%$ & $13 \%$ & $\begin{array}{l}\text { I2-24 } \\
\text { months }\end{array}$ & $\begin{array}{l}\text { Radicular } \\
\text { and/or } \\
\text { axial }\end{array}$ & $\begin{array}{l}\text { Inclusion: trunk/limb } \\
\text { pain refractory to } \\
\text { CMM for >3 months. }\end{array}$ \\
\hline $\begin{array}{l}\text { De Andres } \\
2017^{23}\end{array}$ & $\begin{array}{l}\text { Traditional } \\
\text { vs } 10-\mathrm{kHz} \\
\mathrm{HF}\end{array}$ & 60 & $\begin{array}{l}\text { Overall: } 92 \% \\
\text { I0-kHz HF: } 90 \% \\
\text { Traditional: } 94 \%\end{array}$ & $92 \%$ & $100 \%$ & $0 \%$ & 12 months & Radicular & $\begin{array}{l}\text { Inclusion: PLPS; pain } \\
\text { refractory to CMM } \\
\text { for >6 months } \\
\text { Exclusion: mechanical } \\
\text { low back pain; } \\
\text { coexisting chronic } \\
\text { pain or neurological } \\
\text { disease. }\end{array}$ \\
\hline $\begin{array}{l}\text { Deer et al } \\
2018^{21}\end{array}$ & $\begin{array}{l}\text { Traditional } \\
\text { vs burst }\end{array}$ & 121 & $\begin{array}{l}\text { Overall: } 93 \% \\
\text { Randomized } \\
\text { after trial }\end{array}$ & $83 \%$ & $42 \%$ & $\begin{array}{l}\text { Not } \\
\text { documented }\end{array}$ & $\begin{array}{l}12 \text { to } 24 \\
\text { weeks }\end{array}$ & $\begin{array}{l}\text { Radicular } \\
\text { and/or } \\
\text { axial }\end{array}$ & $\begin{array}{l}\text { Inclusion: trunk and/or } \\
\text { limb pain }>60 \mathrm{~mm} \text { on } \\
\text { VAS during 7-day pain } \\
\text { diary. }\end{array}$ \\
\hline $\begin{array}{l}\text { Mekhail et al } \\
2020^{22}\end{array}$ & $\begin{array}{l}\text { Traditional } \\
\text { vs closed- } \\
\text { loop }\end{array}$ & 134 & $\begin{array}{l}\text { Overall: } 90 \% \\
\text { Closed-loop: } \\
\text { 94\% } \\
\text { Traditional: } 85 \%\end{array}$ & $86 \%$ & $59 \%$ & $\begin{array}{l}\text { Not } \\
\text { documented }\end{array}$ & 12 months & $\begin{array}{l}\text { Radicular } \\
\text { and/or } \\
\text { axial }\end{array}$ & $\begin{array}{l}\text { Inclusion: trunk/limb } \\
\text { pain refractory to } \\
\text { CMM; > }>60 \mathrm{~mm} \text { on } \\
\text { VAS }\end{array}$ \\
\hline
\end{tabular}

Note: All percentages rounded to whole number unless $<1 \%$.

Abbreviations: SCS, spinal cord stimulation; CMM, conventional medical management; I0-kHz HF, $10 \mathrm{kHz}$ high-frequency therapy; VAS, visual analog scale; PLPS, postlaminectomy pain syndrome (ie FBSS, failed back surgery syndrome); NRS, numeric rating scale; ECAP, evoked compound action potential; LM, lead migration; LOP, loss of paresthesia; PIS, pain at incision site; INF, infection; ULP, unsuccessful lead placement; PGPP, pulse generator pocket pain; MS/C, muscle spasm/cramps; USL, unintended stimulation location.

system patients had achieved the primary outcome of $\geq 50 \%$ reduction in overall back and leg pain with no increase in medications (Table 1). This trend was continued at 12 months, $83.1 \%$ of the patients with the closedloop system and $61 \%$ of the patients with the traditional
SCS system met the primary outcome. When specifically examining LBP scores, $81 \%$ of the closed-loop patients and $57 \%$ of the open-loop patients achieved $\geq 50 \%$ reduction in back at three months. When following these patients to 12 months, $80 \%$ of the closed-loop patients 


\begin{tabular}{|c|c|c|c|c|c|c|}
\hline \multicolumn{3}{|c|}{ Average Percent Pain Reduction for SCS at Last Follow-up } & \multirow{2}{*}{$\begin{array}{l}\text { Back Pain } \\
\text { Responder Rates } \\
\text { ( } \geq \mathbf{5 0 \%} \text { Pain } \\
\text { Reduction) }\end{array}$} & \multirow{2}{*}{$\begin{array}{l}\text { Patient } \\
\text { Satisfaction }\end{array}$} & \multirow{2}{*}{$\begin{array}{l}\text { SCS } \\
\text { Complications }\end{array}$} & \multirow[t]{2}{*}{ Comments } \\
\hline Back & Leg & Overall & & & & \\
\hline $13 \%$ & $46 \%$ & Not documented & Not documented & $93 \%$ & $\begin{array}{l}\text { LM }(14 \%) \\
\text { LOP (I2\%) } \\
\text { PIS (I2\%) } \\
\text { INF (10\%) }\end{array}$ & $\begin{array}{l}\text { At } 24 \text { months, PLPS patients } \\
\text { reported sustained pain relief, } \\
\text { improvements with functional } \\
\text { capacity and health-related } \\
\text { quality of life, and satisfaction } \\
\text { with treatment. }\end{array}$ \\
\hline $\begin{array}{l}\text { I0-kHz HF: } 67 \% \\
\text { Traditional: } 44 \%\end{array}$ & $\begin{array}{l}\text { I0-kHz HF: } 70 \% \\
\text { Traditional: } 49 \%\end{array}$ & Not documented & $\begin{array}{l}\text { Back pain - } \\
3 \text { months: } \\
\text { I0-kHz HF: } 84 \% \\
\text { Traditional: } 44 \% \\
6 \text { months: } \\
\text { 10-kHz HF: } 76 \% \\
\text { Traditional: 52\% } \\
\text { I2 months: } \\
\text { I0-kHz HF: 79\% } \\
\text { Traditional: 51\% } \\
24 \text { months: } \\
\text { I0-kHz HF: } 77 \% \\
\text { Traditional: } 49 \%\end{array}$ & $\begin{array}{l}\text { I0-kHz HF: } 83 \% \\
\text { Traditional: } 79 \%\end{array}$ & $\begin{array}{l}\text { PIS (I2\%) } \\
\text { INF (7\%) } \\
\text { LM (5\%) }\end{array}$ & $\begin{array}{l}\text { Results indicate that } 10-\mathrm{kHz} \\
\text { high-frequency therapy is } \\
\text { superior to traditional SCS. }\end{array}$ \\
\hline Not documented & Not documented & $\begin{array}{l}\text { I0-kHz HF: } 24 \% \\
\text { Traditional: } 19 \%\end{array}$ & Not documented & Not documented & LM (13\%) & $\begin{array}{l}\text { Results indicate that PLPS can } \\
\text { be treated with similar } \\
\text { effectiveness by traditional or } \\
10-\mathrm{kHz} \text { therapy. }\end{array}$ \\
\hline $\begin{array}{l}\text { Burst } 5.7 \mathrm{~mm} \text { less } \\
\text { than traditional on } \\
100 \mathrm{~mm} \text { VAS }\end{array}$ & $\begin{array}{l}\text { Burst } 4.7 \mathrm{~mm} \text { less } \\
\text { than traditional on } \\
100 \mathrm{~mm} \text { VAS }\end{array}$ & $\begin{array}{l}\text { Burst } 5.1 \mathrm{~mm} \text { less } \\
\text { than traditional on } \\
100 \mathrm{~mm} \text { VAS }\end{array}$ & Not documented & $89 \%$ & $\begin{array}{l}\text { ULP }(0.6 \%) \\
\text { PIS }(0.6 \%)\end{array}$ & $\begin{array}{l}\text { Purpose of study was to } \\
\text { determine safety and efficacy } \\
\text { of a device capable of } \\
\text { delivering tonic or burst } \\
\text { stimulation. }\end{array}$ \\
\hline $\begin{array}{l}\text { Closed-loop: } 69 \% \\
\text { Traditional: } 54 \%\end{array}$ & $\begin{array}{l}\text { Closed-loop: } 73 \% \\
\text { Traditional: } 62 \%\end{array}$ & $\begin{array}{l}\text { Closed-loop: } 72 \% \\
\text { Traditional: } 56 \%\end{array}$ & $\begin{array}{l}\text { Back pain - } \\
3 \text { months: } \\
\text { Closed-loop: 81\% } \\
\text { Traditional: } 57 \% \\
12 \text { months: } \\
\text { Closed-loop: } 80 \% \\
\text { Traditional: } 58 \%\end{array}$ & Not documented & $\begin{array}{l}\text { LM }(7 \%) \\
\text { PGPP }(4 \%) \\
\text { MS/C (2\%) } \\
\text { USL }(2 \%) \\
\text { INF (I\%) }\end{array}$ & $\begin{array}{l}\text { Evidence indicates superiority } \\
\text { of closed-loop (ECAP } \\
\text { controlled) system. }\end{array}$ \\
\hline
\end{tabular}

and $58 \%$ of the open-loop patients maintained $\geq 50 \%$ back pain reduction. A hypothesized reason for improvement in pain control seen with the closed-loop system was increased time within the therapeutic window for the individuals in the closed-loop group.
In conclusion, the use of a closed-loop SCS system allows for optimal therapeutic effects to be maintained without being diminished by the patient's posture or physical activity. Although further research with longer-term outcome data and a large cohort is necessary, a closed-loop system that 

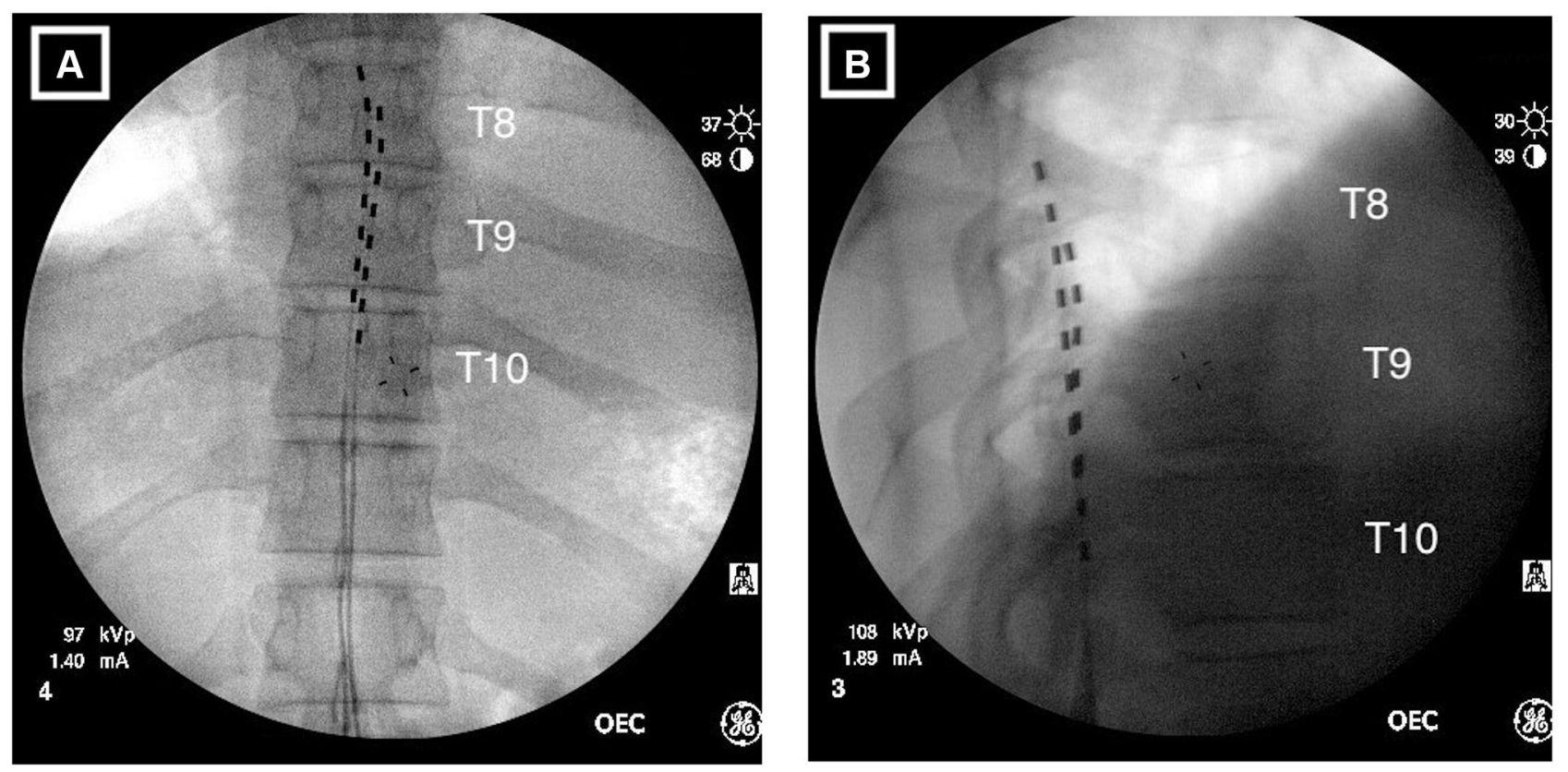

Figure I Radiographical images of implanted percutaneous leads. (A) Anterior/posterior view showing the left lead positioned at the top of T8 with the right lead positioned at the middle of T8. The staggered configuration provides overlap of the T8-T9 disc space and T9-10-disc space corresponding to the targeted dermatomes for low back and leg pain. (B) Lateral view indicating the leads are correctly positioned in the posterior epidural space.

is capable of automatically monitoring and adapting stimulation parameters may prove to be a more efficacious treatment option for those suffering from axial symptoms.

\section{High-density or High-dose SCS}

Within the last few years, clinicians have been altering parameters that influence electrical charge delivery to find efficacious programming parameters that provide paresthesia-free or -reduced SCS pain relief within frequency ranges $\leq 1200 \mathrm{~Hz}$. High-density or highdose (HD) SCS is a proposed programming method to improve pain control with SCS through alterations in pulse width and frequency in order to provide a higher charge delivery over a specific period of time (ie higher charge per second). ${ }^{41}$ A functional MRI study suggested that HD SCS may modulate the descending pain modulatory system in the brain and brainstem regions in humans with PLPS resulting in supraspinal effects and subsequent pain relief. ${ }^{42}$ To date, no RCTs exist examining the ability of HD to provide effective long-term axial LBP (Table 3). Studies have predominantly consisted of retrospective and prospective case series and often include patients with decreasing efficacy with traditional SCS settings that either have neuropathic pain, complex regional pain syndrome (CRPS) or PLPS. ${ }^{43-47}$
The earlier studies with HD suggested limited efficacy in treating PLPS patients with LBP and leg pain (Table 3). ${ }^{25,43,45}$ In two retrospective case series with a minimum of 12 months follow-up, HD programming was shown to have positive effects on pain scores. ${ }^{25,43}$ However, when specifically analyzing PLPS patients with low back and leg pain, response rates and pain reduction were not as great as those seen with individuals suffering from other neuropathic pain states (eg CRPS). Sweet et $\mathrm{al}^{45}$ examined 15 patients responding to conventional SCS in a prospective case series that switched patients to subthreshold HD. Unfortunately, only four of the 15 patients responded to subthreshold HD programming. However, in this subgroup HD programming resulted in improvement in pain control compared to sham and lower levels of focus on the pain compared to conventional programming. Two small retrospective case series with 12 months follow-up also demonstrated limited efficacy in patients with PLPS. ${ }^{25,43}$ The responder rates based on each study definition for PLPS was $22-33 \%$ and in one series many patients aborted HD programming.

Recently, a prospective open label study of 44 SCS naïve patients with PLPS suffering with chronic back and leg pain further examined HD parameters $(1000 \mathrm{~Hz}$ and $90 \mu \mathrm{s}$ or $300 \mathrm{~Hz}$ and $800 \mu \mathrm{s}$ ) for three months and 
Table 2 Modifications to Improve Traditional SCS Low Back Coverage

\begin{tabular}{|c|c|c|c|c|}
\hline Modification & Study & $\begin{array}{l}\text { Pertinent Inclusion and } \\
\text { Exclusion Criteria }\end{array}$ & Findings & Warranted Future Research \\
\hline \multicolumn{5}{|c|}{ Stimulation target zone } \\
\hline $\begin{array}{l}\text { Target region: T9- } \\
\text { TI0 }\end{array}$ & $\begin{array}{l}\text { Sharan et al } \\
2002^{26}\end{array}$ & $\begin{array}{l}\text { Inclusion: previous lumbar } \\
\text { spine surgery. }\end{array}$ & $\begin{array}{l}\text { Cathode positioned at T9-TI0; 6-12 } \\
\text { months postop, most effective } \\
\text { cathode position was at TI0 and } \\
\text { lower. }\end{array}$ & $\begin{array}{l}\text { Further examination of optimal lead } \\
\text { position. }\end{array}$ \\
\hline $\begin{array}{l}\text { Target region: } \\
\text { TIO-TII; modified } \\
\text { anchoring methods }\end{array}$ & $\begin{array}{l}\text { Mironer et al } \\
2008^{27}\end{array}$ & $\begin{array}{l}\text { Inclusion: axial and/or } \\
\text { radicular symptoms } \\
\text { maintained after }>2 \text { years of } \\
\text { SCS treatment. }\end{array}$ & $\begin{array}{l}\text { The use of a single, percutaneous, } \\
\text { octad lead with midline anchoring } \\
\text { allowed for better coverage of axial } \\
\text { and lower extremity pain. }\end{array}$ & $\begin{array}{l}\text { Further examination of optimal lead } \\
\text { selection, lead position, and parameters } \\
\text { of stimulation. }\end{array}$ \\
\hline $\begin{array}{l}\text { Target region: T9- } \\
\text { TI0; non-neuronal } \\
\text { cells in the nervous } \\
\text { system }\end{array}$ & $\begin{array}{l}\text { Ruiz-Sauri } \\
2019^{72}\end{array}$ & $\begin{array}{l}\text { Dissection of posterior spinal } \\
\text { cord segments from II } \\
\text { human cadavers. }\end{array}$ & $\begin{array}{l}\text { Glial to neuronal ratio in posterior gray } \\
\text { matter within the T8- TII vertebral } \\
\text { region ranges from I I:I to I3:I. At T9- } \\
\text { TI0, population of oligodendrocytes is } \\
\text { significantly larger than any other } \\
\text { segment. }\end{array}$ & $\begin{array}{l}\text { Further clinical investigation of the role } \\
\text { of glial cells in the development and } \\
\text { maintenance of chronic pain. The ability } \\
\text { of SCS to modulate glial cells and their } \\
\text { relationship to pain control. }\end{array}$ \\
\hline \multicolumn{5}{|c|}{ Lead design/stimulation parameters } \\
\hline $\begin{array}{l}\text { Anode-Cathode } \\
\text { Configuration }\end{array}$ & $\begin{array}{l}\text { Holsheimer } \\
\text { and Wesselink } \\
1997^{28}\end{array}$ & Computer modeling & $\begin{array}{l}\text { Widest area of coverage found with } \\
\text { bipolar or tripolar configuration on } \\
\text { single electrode. }\end{array}$ & $\begin{array}{l}\text { Further examination of optimal } \\
\text { electrode configuration for low back } \\
\text { coverage }\end{array}$ \\
\hline $\begin{array}{l}\text { Multiple electrode } \\
\text { paddle lead }\end{array}$ & $\begin{array}{l}\text { Barolat et al } \\
2001^{29}\end{array}$ & $\begin{array}{l}\text { Inclusion: Axial symptoms } \geq \\
\text { radicular symptoms. Exclusion: } \\
\text { PLPS patients } \\
\text { excluded if leg pain >back pain. }\end{array}$ & $\begin{array}{l}\text { Multiple electrode paddle lead was found } \\
\text { to decrease leg and back pain, while } \\
\text { improving quality of life at } 6 \text { and } 12 \\
\text { months compared to baseline. }\end{array}$ & $\begin{array}{l}\text { Randomized controlled trial with large } \\
\text { cohort comparing the efficacy of paddle } \\
\text { leads vs percutaneous leads. }\end{array}$ \\
\hline $\begin{array}{l}\text { Multiple electrodes/ } \\
\text { leads }\end{array}$ & $\begin{array}{l}\text { North et al } \\
2005^{30}\end{array}$ & $\begin{array}{l}\text { Inclusion: PLPS with back } \\
\text { pain >leg pain. }\end{array}$ & $\begin{array}{l}\text { There was no advantage in pain } \\
\text { coverage using two 4-electrode leads } \\
\text { vs a single 4-electrode lead. }\end{array}$ & $\begin{array}{l}\text { Further examination of optimal number } \\
\text { of leads and lead spacing. }\end{array}$ \\
\hline $\begin{array}{l}\text { Laminectomy vs } \\
\text { percutaneous } \\
\text { electrodes }\end{array}$ & $\begin{array}{l}\text { North et al } \\
2006^{31}\end{array}$ & $\begin{array}{l}\text { Inclusion: PLPS with back } \\
\text { pain >leg pain. }\end{array}$ & $\begin{array}{l}2 \times 8 \text { paddle lead provided no benefit } \\
\text { over a single Ix4 percutaneous lead } \\
\text { for the treatment of axial pain and } \\
\text { resulted in increased power } \\
\text { requirements. }\end{array}$ & $\begin{array}{l}\text { Longer-term study comparing the } \\
\text { effectiveness of laminectomy vs } \\
\text { percutaneous electrode with new } \\
\text { programming and SCS system designs. }\end{array}$ \\
\hline $\begin{array}{l}\text { Sensor-driven } \\
\text { position-adaptive } \\
\text { system }\end{array}$ & $\begin{array}{l}\text { Schultz et al } \\
2012^{36}\end{array}$ & $\begin{array}{l}\text { Inclusion: axial and/or } \\
\text { radicular symptoms; PLPS } \\
\text { patients included. }\end{array}$ & $\begin{array}{l}\text { Stimulation parameters are altered as } \\
\text { body position changes. }\end{array}$ & $\begin{array}{l}\text { Further examination of sensor-driven } \\
\text { position-adaptive systems }\end{array}$ \\
\hline $\begin{array}{l}\text { Anatomically guided } \\
\text { 3D neural targeting }\end{array}$ & $\begin{array}{l}\text { Veizi et al } \\
2017^{32}\end{array}$ & $\begin{array}{l}\text { Inclusion: PLPS with axial } \\
\text { and/or radicular symptoms. }\end{array}$ & $\begin{array}{l}\text { SCS therapy with 3D neural targeting } \\
\text { algorithm was more effective at } \\
\text { targeting axial symptoms than } \\
\text { traditional SCS stimulation therapy. }\end{array}$ & $\begin{array}{l}\text { Further examination of 3D neural } \\
\text { targeting for axial low back pain with } \\
\text { and without previous lumbar spine } \\
\text { surgery. }\end{array}$ \\
\hline $\begin{array}{l}\text { ECAP controlled } \\
\text { closed-loop system }\end{array}$ & $\begin{array}{l}\text { Mekhail et al } \\
2020^{22}\end{array}$ & $\begin{array}{l}\text { Inclusion: axial and/or } \\
\text { radicular symptoms. }\end{array}$ & $\begin{array}{l}\text { At } 12 \text { months, } 83.1 \% \text { of patients in the } \\
\text { closed-loop group achieved } \geq 50 \% \\
\text { decrease in axial/radicular symptoms } \\
\text { vs } 61.0 \% \text { in the open-loop group. }\end{array}$ & $\begin{array}{l}\text { Development of methods to reduce } \\
\text { the needed energy input to maintain } \\
\text { the ECAP controlled system. }\end{array}$ \\
\hline
\end{tabular}

Note: Adapted from Provenzano DA, Rebman J, Kuhel C, Trenz H, Kilgore J. The efficacy of high-density spinal cord stimulation among trial, implant,and conversion patients: A retrospective case series.Neuromodulation. 2017;20(7):654-660. Copyright 2017, Wolters Kluwer Health, Inc. ${ }^{25}$

Abbreviations: PLPS, postlaminectomy pain syndrome; SCS, spinal cord stimulation; ECAP, evoked compound action potential. 


\section{Conventional (Open-Loop) System}

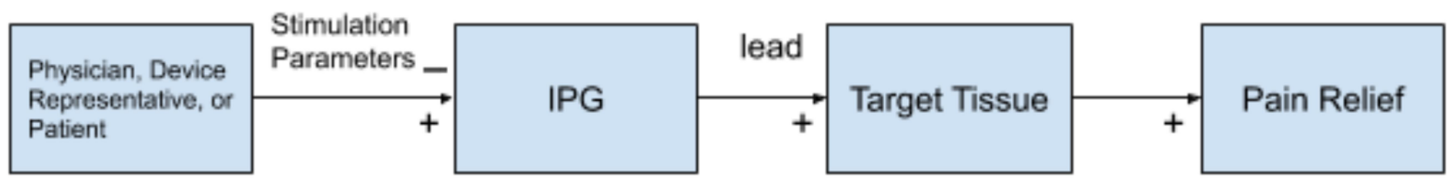

\section{Conventional (Automatic Position Adaptive Simulation) System}

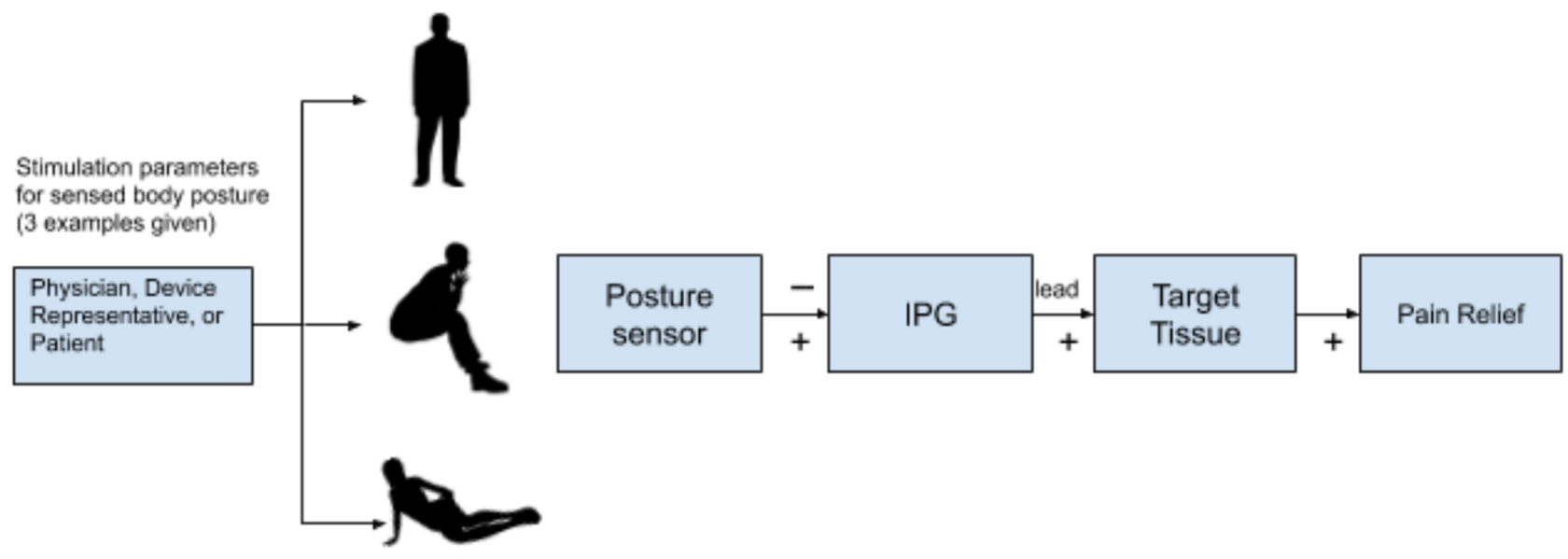

Closed-Loop System

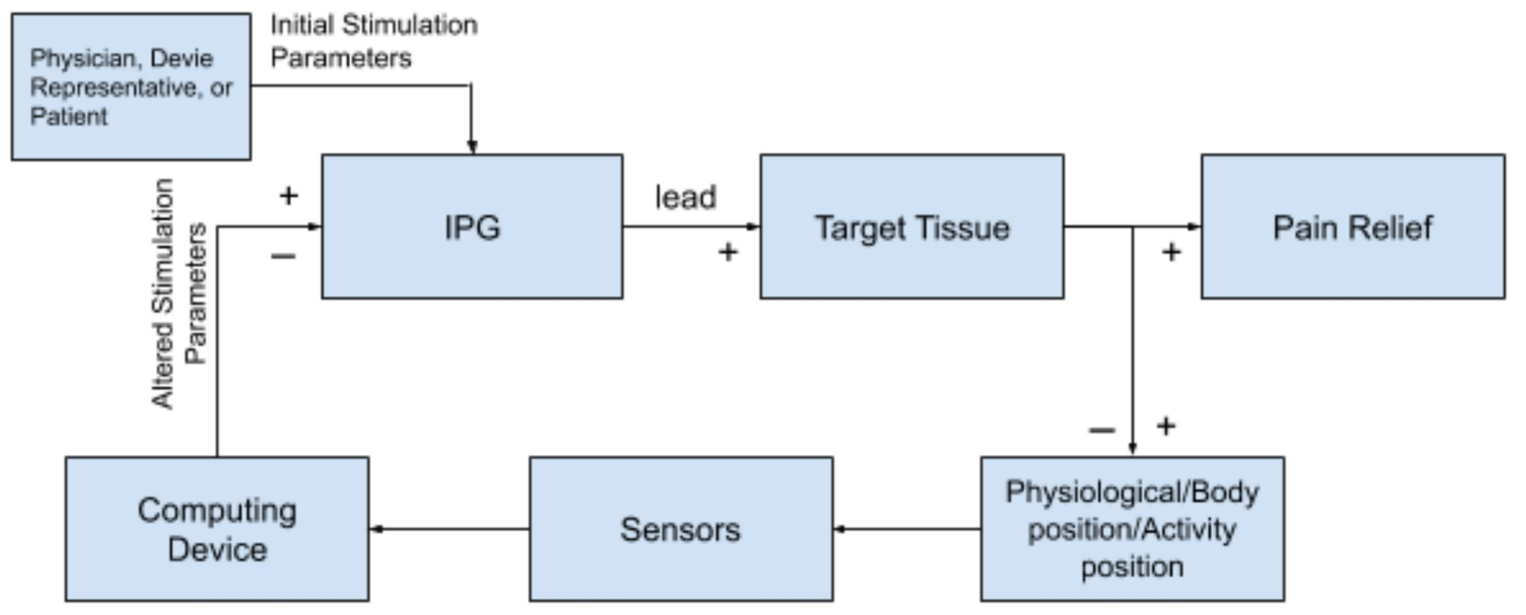

Figure 2 A schematic model depicting the difference in conventional SCS systems compared to closed-loop systems. The conventional system has set stimulation parameters. The closed-loop system alters stimulation parameters depending on the activity, body position, and physiological state of the patient in real time using sensor feedback.

provided insight on the ability to treat $\mathrm{LBP}^{48} \mathrm{HD}$ programming was found to have a significant reduction in overall pain (NRS; 7.5 to $3.8 ; P<0.01$ ), LBP (7.2 to 3.4 ; $P<0.01$ ), leg pain (7.2 to $3.1 ; P<0.01)$ with improvements in functional status (ie Oswestry Disability Index).

Recently, the durability of HD programming was further evaluated in a 12-month prospective single arm multicenter study evaluating individuals with chronic intractable low back and leg pain using a standardized approach to HD programming with 91 patients (103 patients were initially implanted) available at that 12-month follow-up. ${ }^{47}$ At the 12-month visit, there was a statistically significant reduction in overall pain $(56.7 \%)$, LBP (51.9\%) and leg pain (63.7\%) compared to baseline. 
In summary, the research to date on HD programming has demonstrated mixed results with regard to the treatment of axial LBP; especially in individuals with PLPS. In addition, its ability to improve pain control in those that have lost efficacy with traditional SCS has been questioned. ${ }^{44}$ However, the recent single arm prospective study with 12-month data has suggested the sustained ability to treat axial $\mathrm{LBP}^{47}$ Long-term research with a control arm is needed to confirm the results of the longer-term prospective trials. Furthermore, it has been hypothesized that responder rates are improved when mean pulse densities and charge per second are increased. ${ }^{43}$ However, it must be remembered that alterations in frequency and pulse-widths within traditional SCS settings alone without consideration of charge per second or pulse density have been shown to positively influence sensory thresholds (ie mechanical detection and pain pressure thresholds), therapeutic range, paresthesia coverage, and patient sensation/satisfaction scores. ${ }^{49,50}$ Dosing studies have also demonstrated that lower frequencies utilizing lower charge per second may provide equivalent pain relief when pulse-width and amplitude settings are optimized. ${ }^{51}$ Specifically, the PROCO RCT investigated the effects of rate on analgesia in kilohertz frequency $(1-10 \mathrm{kHz})$ in individuals with low back pain with or without equal or lesser leg pain. When pulse width and amplitude were adjusted to optimize subperception SCS therapy while stimulating at the previously identified stimulation location, all tested frequencies provided equivalent pain relief. Therefore, titrating to a specific charge per unit time may not be needed or indicated. No research to date exists regarding the ability of HD to treat nonsurgical refractory LBP.

\section{Burst Spinal Cord Stimulation}

This section will discuss burst stimulation defined by groups of five spikes of energy delivered at $500 \mathrm{~Hz}$ with a pulse width of one millisecond and one millisecond interspike intervals at subthreshold amplitudes followed by a passive discharge phase delivered over five milliseconds. ${ }^{52}$ Burst stimulation was first implemented for the treatment of chronic neuropathic pain in 2010. ${ }^{53}$ Burst SCS may induce distinct patterns of modulation of neurons in the dorsal horn and dorsal column nuclei and brain activation. ${ }^{54}$ To date, limited research is available to evaluate the efficacy of burst SCS in the treatment of axial and nonsurgical refractory LBP. ${ }^{16,55,56}$
Currently, the majority of the research published on burst SCS involves heterogeneous subject populations which makes it challenging to evaluate its efficacy for the treatment of predominant axial LBP. ${ }^{8,16,55}$ To date, only a nonrandomized comparative study exists evaluating the efficacy of burst SCS in the treatment of predominant axial LBP. ${ }^{57}$ In this comparative study between burst and $10-\mathrm{kHz}$ high-frequency SCS $(10-\mathrm{kHz}$ HF), 16 subjects with PLPS were enrolled with predominant LBP $(\geq 70 \%$ of global pain) and results were presented with a mean post-implant follow-up range of 10-20 months. Both therapies demonstrated a significant decrease from baseline to long-term follow-up in mean LBP intensity with no difference between groups $(87.5 \pm 17.7 \%$ and $54.9 \pm 44 \%$ reduction for burst SCS and 10-kHz HF, respectively). ${ }^{57}$

In the largest RCT on burst SCS (SUNBURST TRIAL) the effectiveness of burst stimulation in comparison to tonic stimulation was evaluated in 100 subjects (all candidates for a currently approved neurostimulation device) that were randomized to either treatment and followed for up to one year. ${ }^{21}$ In this study there was a heterogeneous subject population that included patients with back pain, leg pain, nonsurgical refractory low back pain (ie no history of previous back surgery) and other non-spine conditions (eg CRPS). PLPS was diagnosed in $41.8 \%$ of patients. Burst SCS was preferred by $70.8 \%$ of patients. Responders to treatment were classified as individuals achieving $\geq 30 \%$ reduction in overall daily VAS score from baseline. Based on the intention-to-treat analysis, the estimated difference in the overall VAS score between burst and tonic stimulation was $-5.1 \mathrm{~mm}$ on a $0-100 \mathrm{~mm}$ VAS scale. When evaluating the number of patients that had clinically significant reductions in pain ( $\geq 30 \%$ ), $60 \%$ of the burst SCS patient and $51 \%$ of the tonic patients met or exceeded this cutoff (Table 1). Unfortunately, the study did not allow for detailed evaluation of the ability of burst SCS to treat predominantly axial LBP based on the study population and data collected.

Recently, a systematic review and meta-analysis of RCTs and prospective cohort studies was conducted comparing SCS waveforms and programming for treating chronic LBP predominantly in individuals with PLPS. ${ }^{56}$ Specifically, six studies were evaluated comparing burst SCS vs traditional SCS and two studies comparing burst SCS vs $10-\mathrm{kHz}$ HF SCS. Although many studies included a high risk of bias, a meta-analysis of five studies comparing Burst SCS vs traditional SCS revealed pooled superiority of burst over traditional for chronic LBP reduction. ${ }^{56}$ 


\begin{tabular}{|c|c|c|c|}
\hline 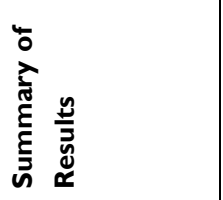 & 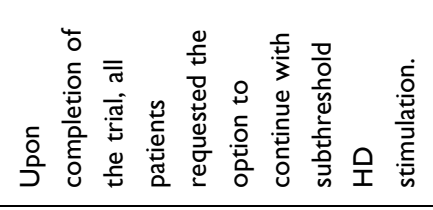 & 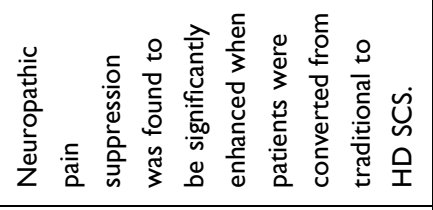 & 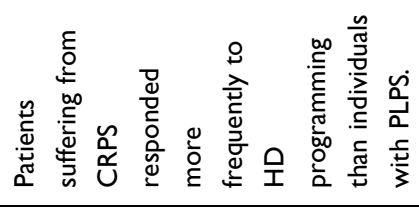 \\
\hline 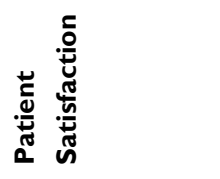 & 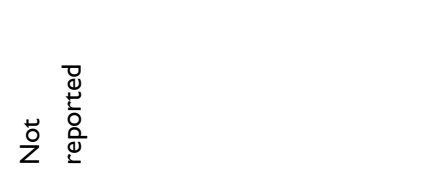 & 蒂 & 蒙 \\
\hline 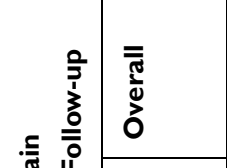 & 苍 & œ̊ & 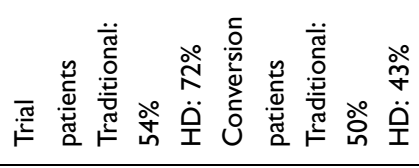 \\
\hline 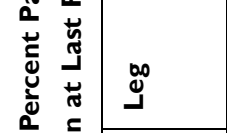 & 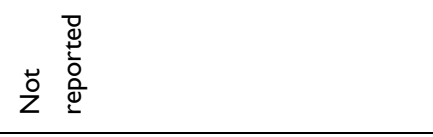 & $\frac{\circ}{n}$ & 兽 \\
\hline 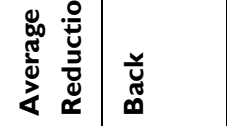 & 雚 & 苍 & 苔 \\
\hline 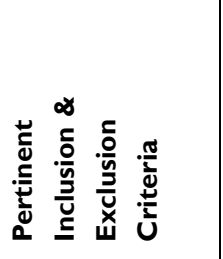 & 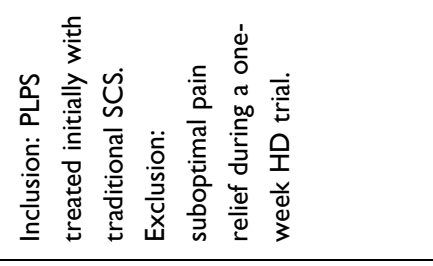 & 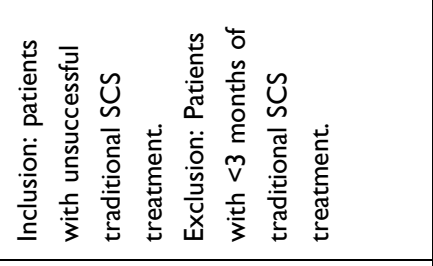 & 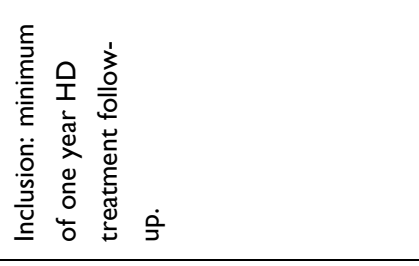 \\
\hline 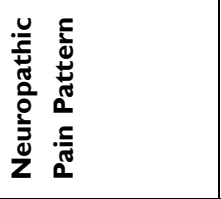 & 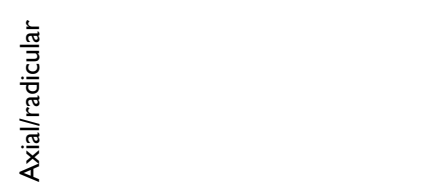 & 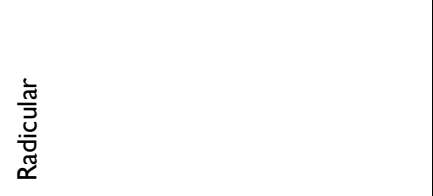 & 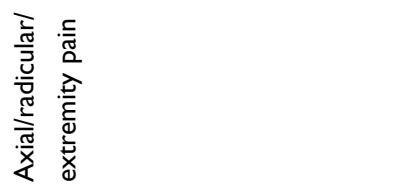 \\
\hline 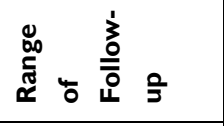 & 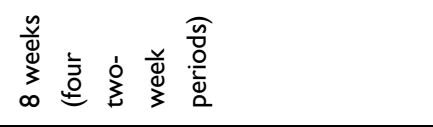 & 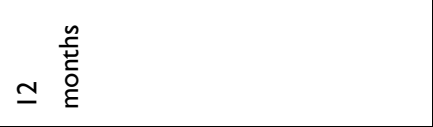 & $\simeq \stackrel{\substack{c \\
\stackrel{5}{E}}}{E}$ \\
\hline 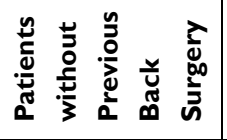 & ○̊ & 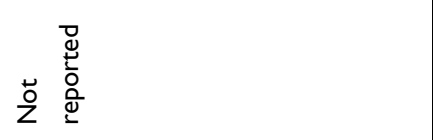 & 苍 \\
\hline 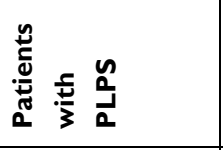 & 응 & $\stackrel{\circ}{\stackrel{\circ}{\kappa}}$ & ڤ̊ํ \\
\hline 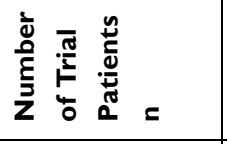 & $\sigma$ & i & 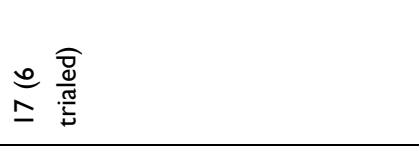 \\
\hline 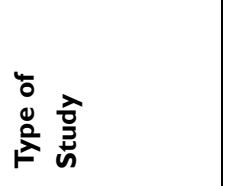 & 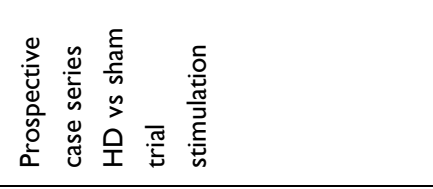 & 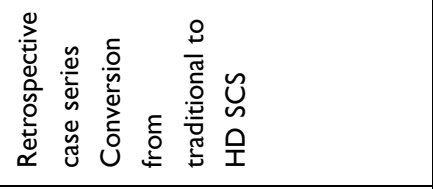 & 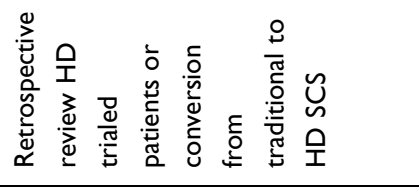 \\
\hline 高 & 芉哭 & 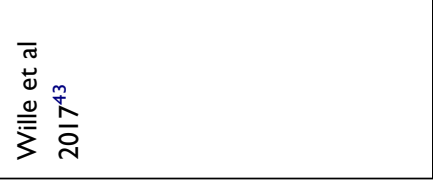 & 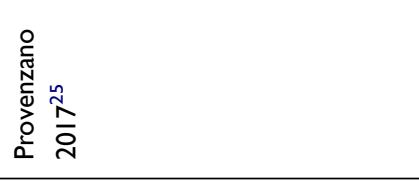 \\
\hline
\end{tabular}




\begin{tabular}{|c|c|c|}
\hline 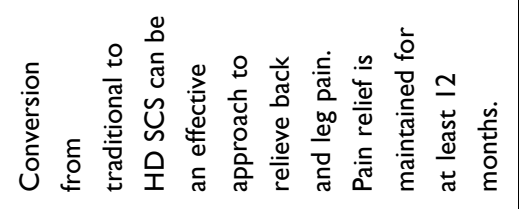 & 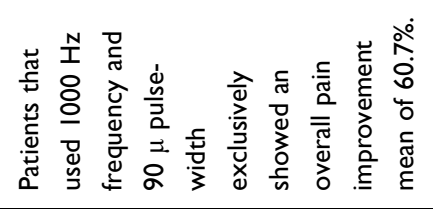 & 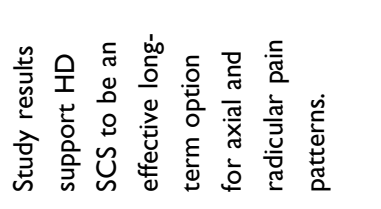 \\
\hline 总 & ఖें & ஹ̊ \\
\hline 总 & 察 & ڤ̊ํ \\
\hline 今. & ஓें & ஓें \\
\hline ஓे & ڤે̊ & సે \\
\hline 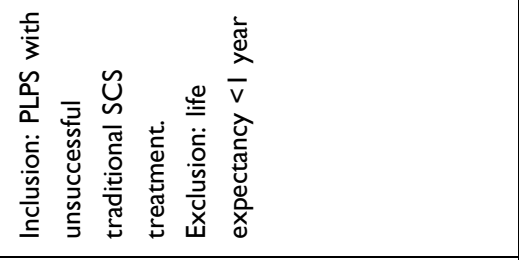 & 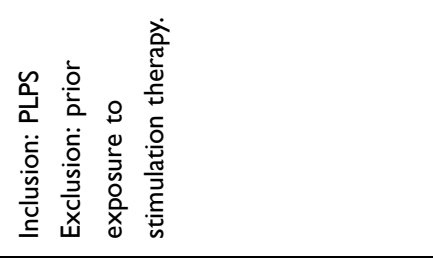 & 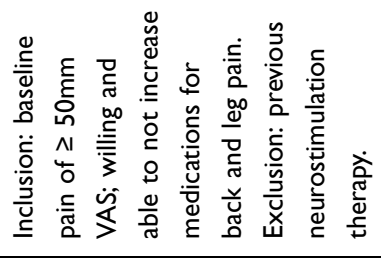 \\
\hline 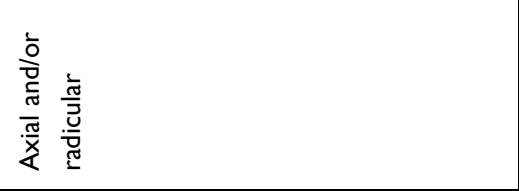 & 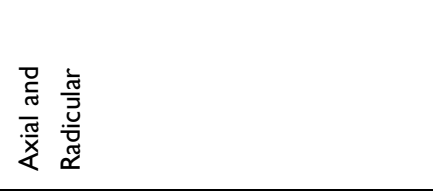 & 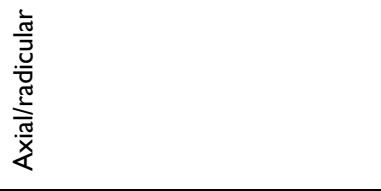 \\
\hline$\simeq \stackrel{\stackrel{n}{\bar{t}}}{\underline{\underline{o}}}$ & 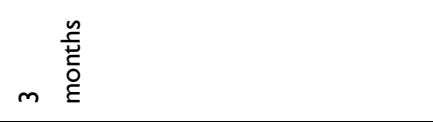 & 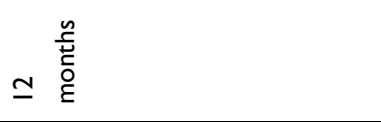 \\
\hline ஃ̊ & $\stackrel{\circ}{\circ}$ & 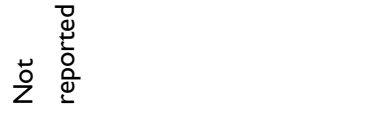 \\
\hline$\stackrel{\circ}{\circ}$ & ㅇํㅇ & 总 \\
\hline 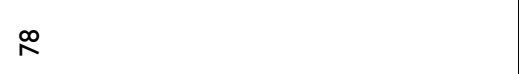 & $\stackrel{\infty}{*}$ & 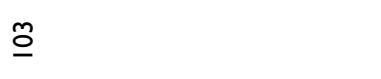 \\
\hline 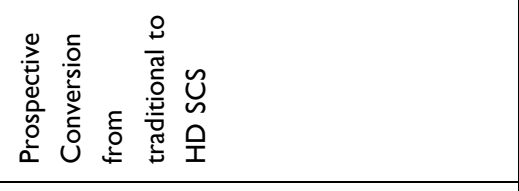 & 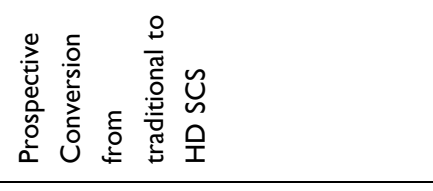 & 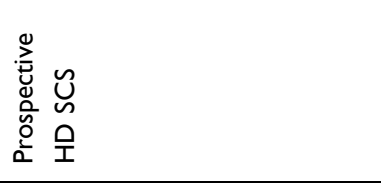 \\
\hline 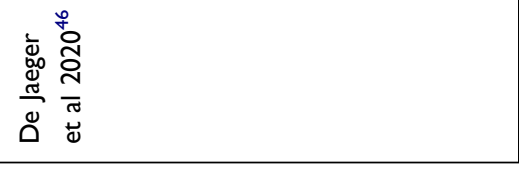 & 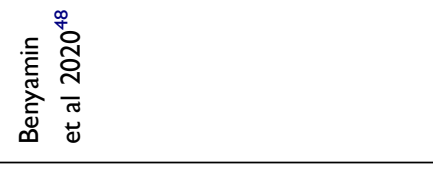 & 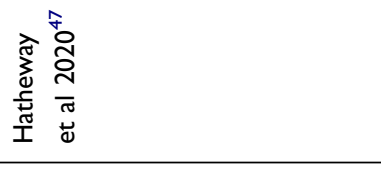 \\
\hline
\end{tabular}


Further examination of burst SCS for the treatment of axial LBP and nonsurgical refractory LBP with longitudinal follow-up is warranted. Studies would benefit from narrowing patient selection to provide optimal insight into the treatment of axial LBP. Recently, additional efforts have been made to improve our understanding of the deployment of burst SCS in the treatment of LBP including the evaluation of lead placement (anatomical placement vs paresthesia mapping), optimization of dosing, and stimulation parameters. ${ }^{58-61}$

\section{I0-kHz High-frequency Therapy}

Ten kilohertz high-frequency therapy utilizes a higher frequency $(10-\mathrm{kHz})$ than that of traditional stimulation as well as substantially shortened pulse-width (30 $\mu \mathrm{s})$ to elicit pain relief without the sensation of paresthesia. ${ }^{62}$ In addition, the pain relief associated with $10-\mathrm{kHz}$ HF therapy is paresthesia independent and therefore leads are placed based on anatomical landmarks. ${ }^{35}$ Previous research has suggested that frequency, as well as other parameters including pulse width and amplitude, is integral in pain reduction. ${ }^{50,51} \mathrm{~A}$ randomized crossover study evaluating subthreshold frequencies of $1200 \mathrm{~Hz}, 3030 \mathrm{~Hz}$, and 5882 $\mathrm{Hz}$, demonstrated that a frequency of $5882 \mathrm{~Hz}$ produced significant axial LBP relief in comparison to lower frequencies and sham SCS. ${ }^{63}$ As with other modes of SCS, the underlying mode of action is still being elicited. Basic science research has suggested that $10-\mathrm{kHz}$ stimulation suppresses spontaneous activity in the dorsal horn and the preferential blockade of large diameter fibers with concomitant recruitment of medium and small fibers. ${ }^{64-66}$ Furthermore, structural volumetric changes in areas of the brain involved in chronic pain processing have been shown to be influenced. ${ }^{67}$ Specifically, significant decreases were found in the volume in the left and right hippocampus over time.

A multicenter RCT with 24-month follow-up and recent systematic review utilizing the Cochrane risk of biased TOOL and GRADE system provide evidence that $10-\mathrm{kHz}$ SCS, when compared to low-frequency SCS, is more effective in patients with axial LBP and concurrent leg pain. ${ }^{13,14,16}$ In the 24-month multicenter RCT conducted, $76.5 \%$ of patients were responders to $10-\mathrm{kHz} \mathrm{HF}$ therapy for LBP compared to $49.3 \%$ for traditional SCS. ${ }^{14}$ In addition, $60 \%$ of patients treated with $10-\mathrm{kHz}$ HF therapy were satisfied with their reduction in pain at 24 months vs only $40.4 \%$ of traditional SCS patients. ${ }^{14}$ In this study $87 \%$ of patient had previous back surgery with baseline back scores $>7$ on the
VAS. The recent systematic review demonstrated lowquality evidence that $10-\mathrm{kHz}$ is effective beyond six months for axial LBP reduction in patients with predominantly axial spine pain and those with mixed axial low back and leg pain. ${ }^{16}$ A non-industry funded SCS study examining 10$\mathrm{kHz} \mathrm{HF}$ to traditional SCS demonstrated no difference in global pain reduction at one year. ${ }^{68}$ However, back pain scores were not reported separately. ${ }^{68}$

Initial research has investigated the ability of $10-\mathrm{kHz} \mathrm{HF}$ therapy to treat nonsurgical refractory $\mathrm{LBP}^{69}$ In a prospective open label study of individuals with chronic axial LBP without previous spinal surgery, 21 patients were examined. $95 \%$ of the patients went on to implantation and 17 patients were followed for 36 months. Significant reduction in pain $(79 \pm 12 \mathrm{~mm}$ to $10 \pm 12 \mathrm{~mm})$, improvement in functional status, and reduction in opioid utilization were demonstrated. A subanalysis of pooled data from two prospective studies evaluating $10-\mathrm{kHz}$ HF therapy for the treatment of nonsurgical refractory back pain demonstrated a $70 \%$ reduction in average back pain and improvement in Oswestry disability index (ODI) with reduced opioid consumption at 12 months in the combined cohort. ${ }^{1}$

\section{Differential Target Multiplexed SCS}

Differential target multiplexed SCS is a novel programming approach based on evidence from preclinical studies. $^{64,70}$ Differential target multiplexed stimulation uses multiple electrical signals that differ from one another in electrical wave parameters which has been suggested to stimulate multiple target tissues including pain fibers in the dorsal column and modulate glial cells in the spinal cord. ${ }^{70}$ Differential target multiplexed stimulation aims to modulate chronic pain-related biological processes back toward their non-pain state. ${ }^{71}$ Basic science research has indicated that glial cells outnumber neurons in the spinal cord 20:1, are electrically excitable, and have the ability to modulate ascending pain pathways. ${ }^{72,73}$ This evidence allowed researchers to hypothesize that SCS parameters can be adjusted to differentially target neurons and glial cells in order to maximize the efficacy of treatment. ${ }^{64}$

A prospective multicenter feasibility dual trial study was conducted with 25 patients with chronic intractable back pain with or without leg pain that underwent a threeto-five-day SCS trial using traditional stimulation followed by a three-to-five-day trial using differential target multiplexed stimulation. The trial periods were separated by a 24 -h washout period. ${ }^{70}$ Differential target multiplexed therapy resulted in a $\geq 50 \%$ back pain relief in $80 \%$ of the 
patients while traditional SCS provided $\geq 50 \%$ relief in $50 \%$ of the patients. Specifically, differential target multiplexed therapy resulted in a $67 \%$ reduction in LBP compared to baseline while traditional SCS resulted in a $43 \%$ reduction from baseline $(P<0.0001)$.

Further published studies evaluating the efficacy of differential target multiplexed programming in a RCT setting with longer-term follow-up (minimum of 12 to 24 months) and refinements of the study population are needed to evaluate the long-term effectiveness in treating axial LBP and nonsurgical LBP.

\section{Dorsal Root Ganglion Stimulation}

Preliminary research has examined the utilization of DRG stimulation to treat chronic low back pain. ${ }^{74-78}$ The DRG contains the primary sensory neurons that transmit afferent nociception. $^{74}$ Currently, DRG stimulation is FDA approved for the treatment of complex regional pain syndrome of the lower limbs. To date, four case series with a total of 60 patients have examined the effectiveness of DRG specifically for the treatment of low back pain with 12-month follow-up available in some studies. ${ }^{75-78}$ Dorsal root ganglions that were specifically stimulated included $\mathrm{T} 12,^{75}$ and L1-L5 ${ }^{76-78}$ In these case series, DRG stimulation has been shown to improve pain levels, physical and mental functioning, disability, and quality of life. Future well-developed RCTs with long-term follow-up are needed to confirm these initial findings including safety outcomes. $^{79,80}$ Furthermore, the optimal DRG stimulation level for the treatment of chronic axial lumbar pain needs to be further refined.

\section{Peripheral Nerve Stimulation (Medial Branch Nerve Innervation to the Multifidus Muscle)}

Forms of electrical stimulation for the treatment of axial LBP include other modalities besides those that target the dorsal columns. Stimulation of the medial branch nerves innervating the multifidus muscle is one type of non-spinal cord stimulation that has shown promising results. ${ }^{81}$

The multifidus muscle extends lengthwise on either side of the spinal column from the cervical region to the sacral region and acts as an extensor and back stabilizer. Lumbar multifidus muscles generate large forces over short distances for intersegmental control. ${ }^{81,82}$ Functional instability due to weakness of the lumbar multifidus muscle is a significant contributor to axial LBP. ${ }^{82}$ Physiotherapy is often used as a noninvasive treatment option to strengthen the multifidus muscle and reduce axial symptoms; however, long-term relief may be challenging secondary to compliance. Multifidus stimulation is conducted using percutaneous electrodes implanted over the relevant medial branches. Efficacy of the treatment is associated with thickening of the multifidus muscle. ${ }^{83}$ A study conducted by Sions et $\mathrm{al}^{83}$ indicated an average of $20.38 \%$ thickening of the lumbar multifidus muscles utilizing multifidus stimulation therapy. Deckers et $\mathrm{al}^{81}$ conducted a study using multifidus stimulation on 53 subjects with chronic mechanical LBP. Leads were placed bilaterally over the L2 medial branch nerves at the junction of the transverse process and superior articular process. After 90 days, 58\% of subjects had $\geq 2$-point reduction in NRS pain scores. At 12 months, $57 \%$ had $\geq 2$-point reduction in NRS pain scores and $60 \%$ had $\geq 10$-point improvement in ODI. Eighty-one percent of patients in this study were satisfied with their treatment after one year. Cohen et $\mathrm{al}^{84}$ performed a case series of nine subjects using temporary (one-month) percutaneous multifidus stimulation for chronic LBP. Using ultrasound guidance, electrodes were placed $1-2 \mathrm{~cm}$ posterior to the lamina at the center of the patients reported pain to target the medial branch of the dorsal primary ramus. At one month, $67 \%$ of patients reported $\geq 50 \%$ reduction in LBP. Among responders, an $80 \%$ reduction in LBP was achieved. Pain reduction was maintained at $80 \%$ of baseline pain for three months after lead removal and gradually increased to $60 \%$ of baseline pain at six months after lead removal.

Stimulation methods that target painful areas more directly than conventional SCS modalities show promising results. Although currently there is not overwhelming evidence to support the use of these treatment modalities. Multifidus stimulation may be effective at treating symptoms related to muscle weakness in the lumbar region; however, symptoms relating to neuropathic pain will presumably remain. Additional studies looking at the use of multifidus stimulation for chronic LBP are needed.

\section{Conclusion}

Spinal cord stimulation and peripheral nerve stimulation have been studied extensively for the last half century. Recently, attention has been placed on the ability of neurostimulation to treat axial LBP and refractory nonsurgical LBP. Current evidence of efficacy specifically restricted to these conditions is limited. A majority of 
SCS research evaluating treatment efficacy for axial LBP include industry sponsored studies with heterogeneous patient populations often with radicular symptoms and history of prior back surgery. Traditional SCS has demonstrated long-term efficacy for treating radicular symptoms, but limited efficacy for the treatment of axial LBP. Multiple enhancements and modifications in traditional SCS including our understanding of stimulation target zones, electrode placement, electrical parameters, and equipment design modifications may result in improved outcomes. Furthermore, advancements in novel programming, electrical signaling, energy delivery, waveforms and technologies have allowed for the ability to treat pain in a paresthesia independent manner. Neurostimulation therapies that do not target the spinal cord may also be associated with significant axial LBP reduction.

Finally, the minimal invasiveness of neurostimulation remains a compelling reason for patients to seek this treatment option for the treatment of axial low back pain. Invasive surgical methods (eg fusion) that alter the anatomy of the spine with considerable rates of failure and high adverse event rates are often considered before neurostimulation. If neurostimulation is shown to demonstrate long-term effectiveness in appropriately designed RCTs with low complication and explant rates, then neurostimulation therapies may move up in the treatment algorithm for chronic axial LBP and refractory nonsurgical LBP.

\section{Abbreviations}

SCS, spinal cord stimulation; NASS, North American Spine Society; LBP, low back pain; HD, high density; 10-kHz HF, $10 \mathrm{kHz}$ high-frequency therapy; CMM, conservative medical management; QALY, quality adjusted life year; IPG, internal pulse generator; FBSS, failed back surgery syndrome; PLPS, post laminectomy pain syndrome.

\section{Funding}

No funding was obtained for the writing of this manuscript.

\section{Disclosure}

Dr Provenzano has consulted for Abbott, Avanos, Boston Scientific, Esteve, Medtronic, Nevro, Stimgenics and Heron; has received research support from Avanos, Medtronic, Nevro, Stimgenics, and
Abbott; and is an owner of Western PA Surgical Center. Dr Hanes has consulted for Medtronic, Abbott and Boston Scientific; has received research support from Boston Scientific; and is an owner of Jax Spine $\&$ Pain Centers. The authors report no other potential conflicts of interest in this work.

\section{References}

1. Al-Kaisy A, Van Buyten JP, Kapural L, et al. $10 \mathrm{kHz}$ spinal cord stimulation for the treatment of non-surgical refractory back pain: subanalysis of pooled data from two prospective studies. Anaesthesia. 2020;75(6):775-784. doi:10.1111/anae.15036

2. Sinclair C, Verrills P, Barnard A. A review of spinal cord stimulation systems for chronic pain. J Pain Res. 2016;9:481-492. doi:10.2147/ JPR.S108884

3. Lamer TJ. Global, regional, and national incidence, prevalence, and years lived with disability for 354 diseases and injuries for 195 countries and territories, 1990-2017: a systematic analysis for the Global Burden of Disease Study 2017. Lancet. 2018;392(1015 9):1789-1858.

4. Dagenais S, Caro J, Haldeman S. A systematic review of low back pain cost of illness studies in the United States and internationally. Spine J. 2008;8(1):8-20. doi:10.1016/j.spinee.2007.10.005

5. Andersson GB. Epidemiological features of chronic low-back pain. Lancet. 1999;354(9178):581-585. doi:10.1016/S0140-6736(99)013 $12-4$

6. Kreiner DS, Matz P, Bono CM, et al. Guideline summary review: an evidence-based clinical guideline for the diagnosis and treatment of low back pain. Spine J. 2020;20(7):998-1024. doi:10.1016/j.spinee. 20

20.04.006

7. Shealy CN, Taslitz N, Mortimer JT, Becker DP. Electrical inhibition of pain: experimental evaluation. Anesth Analg. 1967;46(3):299-305. doi:10.1213/00000539-196705000-00009

8. Deer TR, Grider JS, Lamer TJ, et al. A Systematic Literature Review of Spine Neurostimulation Therapies for the Treatment of Pain. Pain Med. 2020;21(7):1421-1432. doi:10.1093/pm/pnz353

9. Taylor RS, Ryan J, O’Donnell R, Eldabe S, Kumar K, North RB. The cost-effectiveness of spinal cord stimulation in the treatment of failed back surgery syndrome. Clin J Pain. 2010;26(6):463-469. doi:10.1097/AJP.0b013e3181daccec

10. Kumar K, Caraway DL, Rizvi S, Bishop S. Current challenges in spinal cord stimulation. Neuromodulation. 2014;17(Suppl 1):22-35. doi:10.1111/ner.12172

11. Palmer N, Guan Z, Chai NC. Spinal Cord Stimulation for Failed Back Surgery Syndrome - Patient Selection Considerations. Translat Perioperative Pain Med. 2019;6(3):81-90.

12. Kumar K, Taylor RS, Jacques L, et al. The effects of spinal cord stimulation in neuropathic pain are sustained: a 24-month follow-up of the prospective randomized controlled multicenter trial of the effectiveness of spinal cord stimulation. Neurosurgery. 2008;63 (4):762-770. doi:10.1227/01.NEU.0000325731.46702.D9

13. Kapural L, Yu C, Doust MW, et al. Novel 10-kHz High-frequency therapy (HF10 therapy) Is superior to traditional low-frequency spinal cord stimulation for the treatment of chronic back and leg pain: the SENZA-RCT randomized controlled trial. Anesthesiology. 2015;123(4):851-860. doi:10.1097/ALN.0000000000000774

14. Kapural L, Yu C, Doust MW, et al. Comparison of $10-\mathrm{kHz}$ high-frequency and traditional low-frequency spinal cord stimulation for the treatment of chronic back and leg pain: 24-month results from a multicenter, randomized, controlled pivotal trial. Neurosurgery. 2016;79(5):667-677. doi:10.1227/NEU.0000000000001418 
15. Provenzano DA, Amirdelfan K, Kapural L, Sitzman BT. Evidence gaps in the use of spinal cord stimulation for treating chronic spine conditions. Spine. 2017;42:S80-S92. doi:10.1097/BRS.0000000000002184

16. Conger A, Sperry BP, Cheney CW, et al. The effectiveness of spinal cord stimulation for the treatment of axial low back pain: A systematic review with narrative synthesis. Pain Med. 2020;21 (11):2699-2712. doi:10.1093/pm/pnaa142

17. Al-Kaisy A, Royds J, Al-Kaisy O, et al. Explant rates of electrical neuromodulation devices in 1177 patients in a single center over an 11-year period. Reg Anesth Pain Med. 2020;45(11):883-890. doi:10.1136/rapm-2020-101681

18. Van Buyten JP, Wille F, Smet I, et al. Therapy-related explants after spinal cord stimulation: results of an international retrospective chart review study. Neuromodulation. 2017;20(7):642-649. doi:10.1111/ner.12642

19. Hayek SM, Veizi E, Hanes M. Treatmentlimiting complications of percutaneous spinal cord stimulator implants: A review of eight years of experience from an academic center database. Neuromodulation. 2015;18(7):603-609. doi:10.1111/ner.12312

20. Pope JE, Deer TR, Falowski S, et al. Multicenter retrospective study of neurostimulation with exit of therapy by explant. Neuromodulation. 2017;20(6):543-552. doi:10.1111/ner.12634

21. Deer T, Slavin KV, Amirdelfan K, et al. Success using neuromodulation with BURST (SUNBURST) study: results from a prospective, randomized controlled trial using a novel burst waveform. Neuromodulation. 2018;21(1):56-66. doi:10.1111/ner.12698

22. Mekhail N, Levy RM, Deer TR, et al. Long-term safety and efficacy of closed-loop spinal cord stimulation to treat chronic back and leg pain (Evoke): a double-blind, randomised, controlled trial. Lancet Neurology. 2020;19(2):123-134. doi:10.1016/S1474-4422(19)30414-4

23. De Andres J, Monsalve-Dolz V, Fabregat-Cid G, et al. Prospective, randomized blind effect-on-outcome study of conventional vs high-frequency spinal cord stimulation in patients with pain and disability due to failed back surgery syndrome. Pain Med. 2017;18(12):2401-2421.

24. Kumar K, Taylor RS, Jacques L, et al. Spinal cord stimulation versus conventional medical management for neuropathic pain: a multicentre randomised controlled trial in patients with failed back surgery syndrome. Pain. 2007;132(1):179-188. doi:10.1016/j.pain.2007.07.028

25. Provenzano DA, Rebman J, Kuhel C, Trenz H, Kilgore J. The efficacy of high-density spinal cord stimulation among trial, implant, and conversion patients: A retrospective case series. Neuromodulation. 2017;20(7):654-660. doi:10.1111/ner.12612

26. Sharan A, Cameron T, Barolat G. Evolving patterns of spinal cord stimulation in patients implanted for intractable low back and leg pain. Neuromodulation. 2002;5(3):167-179. doi:10.1046/j.1525-14 03.2002.02027.x

27. Mironer YE, Satterthwaite JR, Lewis EM, et al. Efficacy of a single, percutaneous, across midline, Octrode ${ }^{\circledR}$ lead using a "midline anchoring" technique in the treatment of chronic low back and/or lower extremity pain: A retrospective study. Neuromodulation. 2008;11 (4):286-295. doi:10.1111/j.1525-1403.2008.00178.x

28. Holsheimer J, Wesselink WA. Effect of anode-cathode configuration on paresthesia coverage in spinal cord stimulation. Neurosurgery. 1997;41(3):654-659. doi:10.1097/00006123-199709000-00030

29. Barolat G, Oakley JC, Law JD, North RB, Ketcik B, Sharan A. Epidural spinal cord stimulation with a multiple electrode paddle lead is effective in treating intractable low back pain. Neuromodulation. 2001;4(2):59-66. doi:10.1046/j.1525-1403.2001.00059.x

30. North RB, Kidd DH, Olin J, et al. Spinal cord stimulation for axial low back pain: a prospective, controlled trial comparing dual with single percutaneous electrodes. Spine. 2005;30(12):1412-1418. doi:10.1097/01.brs.0000166502.05449.a8

31. North RB, Kidd DH, Olin J, Sieracki JN, Petrucci L. Spinal cord stimulation for axial low back pain: a prospective controlled trial comparing 16-contact insulated electrodes with 4-contact percutaneous electrodes. Neuromodulation. 2006;9(1):56-67. doi:10.1111/ j.1525-1403.2006.00043.x
32. Veizi E, Hayek SM, North J, et al. Spinal cord stimulation (SCS) with anatomically guided (3D) neural targeting shows superior chronic axial low back pain relief compared to traditional SCS-LUMINA study. Pain Med. 2017;18(8):1534-1548. doi:10. 1093/pm/pnw286

33. Deer T, Pope J, Hayek S, et al. Neurostimulation for the treatment of axial back pain: a review of mechanisms, techniques, outcomes, and future advances. Neuromodulation. 2014;17(Suppl 2):52-68. doi:10. 1111/j.1525-1403.2012.00530.x

34. North RB, Ewend MG, Lawton MT, Piantadosi S. Spinal cord stimulation for chronic, intractable pain: superiority of "multi-channel" devices. Pain. 1991;44(2):119-130. doi:10.1016/0304-3959(91) 90125-H

35. De Carolis G, Paroli M, Tollapi L, et al. Paresthesia-independence: an assessment of technical factors related to $10 \mathrm{kHz}$ paresthesia-free spinal cord stimulation. Pain Phys. 2017;20(4):331-341.

36. Schultz DM, Webster L, Kosek P, Dar U, Tan Y, Sun M. Sensordriven position-adaptive spinal cord stimulation for chronic pain. Pain Phys. 2012;15(1):1-12.

37. Denison T, Litt B. Advancing neuromodulation through control systems: a general framework and case study in posture-responsive stimulation. Neuromodulation. 2014;17(Suppl 1):48-57. doi:10.1111/ner. 12170

38. Sun FT, Morrell MJ. Closed-loop neurostimulation: the clinical experience. Neurotherapeutics. 2014;11(3):553-563. doi:10.1007/ s13311-014-0280-3

39. Russo M, Cousins MJ, Brooker C, et al. Effective relief of pain and associated symptoms with closed-loop spinal cord stimulation system: preliminary results of the Avalon Study. Neuromodulation. 2018;21(1):38-47. doi:10.1111/ner.12684

40. Russo M, Brooker C, Cousins MJ, et al. Sustained long-term outcomes with closed-loop spinal cord stimulation: 12-month results of the prospective, multicenter, open-label Avalon Study. Neurosurgery. 2020;87(4):E485-e495. doi:10.1093/neuros/nyaa003

41. Miller JP, Eldabe S, Buchser E, Johanek LM, Guan Y, Linderoth B. Parameters of spinal cord stimulation and their role in electrical charge delivery: a review. Neuromodulation. 2016;19(4):373-384. doi:10.1111/ner. 12438

42. De Groote S, Goudman L, Peeters R, et al. The influence of high dose spinal cord stimulation on the descending pain modulatory system in patients with failed back surgery syndrome. NeuroImage: Clinical. 2019;24:102087. doi:10.1016/j.nicl.2019.102087

43. Wille F, Breel JS, Bakker EWP, Hollmann MW. Altering conventional to high density spinal cord stimulation: an energy dose-response relationship in neuropathic pain therapy. Neuromodulation. 2017;20(1):71-80. doi:10.1111/ner.12529

44. Kapural L, Harandi S. Long-term efficacy of 1-1.2 kHz subthreshold spinal cord stimulation following failed traditional spinal cord stimulation: a retrospective case series. Reg Anesth Pain Med. 2019;44 (1):107-110. doi:10.1136/rapm-2018-000003

45. Sweet J, Badjatiya A, Tan D, Miller J. Paresthesia-free high-density spinal cord stimulation for postlaminectomy syndrome in a prescreened population: a prospective case series. Neuromodulation. 2016;19(3):260-267. doi:10.1111/ner.12357

46. De Jaeger M, Goudman L, Brouns R, et al. The long-term response to high-dose spinal cord stimulation in patients with failed back surgery syndrome after conversion from standard spinal cord stimulation: an effectiveness and prediction study. Neuromodulation. 2020. doi:10.1111/ner. 13138

47. Hatheway J, Mangal V, Fishman M, et al. Long-term efficacy of a novel spinal cord stimulation clinical workflow using kilohertz stimulation: twelve-month results from the vectors study. Neuromodulation. 2020. doi:10.1111/ner.13324

48. Benyamin R, Galan V, Hatheway J, et al. Options: a prospective, open-label study of high-dose spinal cord stimulation in patients with chronic back and leg pain. Pain Phys. 2020;23(1):87-98. 
49. Abejon D, Rueda P, Del Saz J, Arango S, Monzon E, Gilsanz F. Is the introduction of another variable to the strength-duration curve necessary in neurostimulation? Neuromodulation. 2015;18(3):182-190. doi:10.1111/ner. 12223

50. Youn Y, Smith H, Morris B, Argoff C, Pilitsis JG. The Effect of High-Frequency Stimulation on Sensory Thresholds in Chronic Pain Patients. Stereotact Funct Neurosurg. 2015;93(5):355-359. doi:10.11 59/000438998

51. Thomson SJ, Tavakkolizadeh M, Love-Jones S, et al. Effects of rate on analgesia in kilohertz frequency spinal cord stimulation: results of the PROCO randomized controlled trial. Neuromodulation. 2018;21 (1):67-76. doi:10.1111/ner.12746

52. De Ridder D, Plazier M, Kamerling N, Menovsky T, Vanneste S. Burst spinal cord stimulation for limb and back pain. World Neurosurg. 2013;80(5):642-649. doi:10.1016/j.wneu.2013.01.040

53. De Ridder D, Vanneste S, Plazier M, van der Loo E, Menovsky T. Burst spinal cord stimulation: toward paresthesia-free pain suppression. Neurosurgery. 2010;66(5):986-990. doi:10.1227/01. NEU.0000368153.44883.B3

54. Chakravarthy K, Fishman MA, Zuidema X, Hunter CW, Levy R. Mechanism of action in burst spinal cord stimulation: review and recent advances. Pain Med. 2019;20(Suppl Supplement_1):S13-s22. doi:10.1093/pm/pnz073

55. Lamer TJ, Moeschler SM, Gazelka HM, Hooten WM, Bendel MA, Murad MH. Spinal stimulation for the treatment of intractable spine and limb pain: a systematic review of RCTs and meta-analysis. Mayo Clin Proc. 2019;94(8):1475-1487. doi:10.1016/j.mayocp.2018.12.037

56. Karri J, Orhurhu V, Wahezi S, Tang T, Deer T, Abd-Elsayed A. Comparison of spinal cord stimulation waveforms for treating chronic low back pain: systematic review and meta-analysis.. Pain Phys. 2020;23 (5):451-460.

57. Muhammad S, Roeske S, Chaudhry SR, Kinfe TM. Burst or high-frequency $(10 \mathrm{kHz})$ spinal cord stimulation in failed back surgery syndrome patients with predominant back pain: one year comparative data. Neuromodulation. 2017;20(7):661-667. doi:10.1111/ner.12611

58. Al-Kaisy A, Baranidharan G, Palmisani S, et al. Comparison of paresthesia mapping to anatomical placement in burst spinal cord stimulation: initial trial results of the prospective, multicenter, randomized, double-blinded, crossover, crisp study. Neuromodulation. 2020;23(5):613-619. doi:10.1111/ner.13104

59. Schu S, Slotty PJ, Bara G, von Knop M, Edgar D, Vesper J. A prospective, randomised, double-blind, placebo-controlled study to examine the effectiveness of burst spinal cord stimulation patterns for the treatment of failed back surgery syndrome. Neuromodulation. 2014;17(5):443-450. doi:10.1111/ner.12197

60. Vesper J, Slotty P, Schu S, et al. Burst SCS Microdosing is as efficacious as standard burst scs in treating chronic back and leg pain: results from a randomized controlled trial. Neuromodulation. 2019;22(2):190-193. doi:10.1111/ner.12883

61. Van Havenbergh T, Vancamp T, Van Looy P, Vanneste S, De Ridder D. Spinal cord stimulation for the treatment of chronic back pain patients: $500-\mathrm{Hz}$ vs. $1000-\mathrm{Hz}$ burst stimulation. Neuromodulation. 2015;18(1):9-12. doi:10.1111/ner.12252

62. Russo M, Van Buyten J-P. 10-kHz high-frequency SCS therapy: a clinical summary. Pain Med. 2015;16(5):934-942. doi:10.1111/pme.12617

63. Al-Kaisy A, Palmisani S, Pang D, et al. Prospective, randomized, sham-control, double blind, crossover trial of subthreshold spinal cord stimulation at various kilohertz frequencies in subjects suffering from failed back surgery syndrome (SCS Frequency Study). Neuromodulation. 2018;21(5):457-465. doi:10.1111/ ner. 12771

64. Vallejo R, Kelley CA, Gupta A, Smith WJ, Vallejo A, Cedeño DL. Modulation of neuroglial interactions using differential target multiplexed spinal cord stimulation in an animal model of neuropathic pain. Mol Pain. 2020;16:1744806920918057. doi:10.1177/17448 06920918057
65. Vallejo R, Bradley K, Kapural L. Spinal cord stimulation in chronic pain: mode of action. Spine. 2017;42:S53-S60. doi:10.1097/ BRS.0000000000002179

66. Arle JE, Mei L, Carlson KW, Shils JL. High-frequency stimulation of dorsal column axons: potential underlying mechanism of paresthesia-free neuropathic pain relief. Neuromodulation. 2016;19 (4):385-397. doi:10.1111/ner. 12436

67. De Groote S, Goudman L, Van Schuerbeek P, et al. Effects of spinal cord stimulation on voxel-based brain morphometry in patients with failed back surgery syndrome. Clin Neurophysiol. 2020;131(11):2578-2587. doi:10.1016/j.clinph.2020. 07.024

68. De Andres J, Monsalve-Dolz V, Fabregat-Cid G, et al. Prospective, randomized blind effect-on-outcome study of conventional vs high-frequency spinal cord stimulation in patients with pain and disability due to failed back surgery Syndrome. Pain Med. 2017;18 (12):2401-2421. doi:10.1093/pm/pnx241

69. Al-Kaisy A, Palmisani S, Smith TE, et al. Long-term improvements in chronic axial low back pain patients without previous spinal surgery: a cohort analysis of $10-\mathrm{kHz}$ high-frequency spinal cord stimulation over 36 months. Pain Med. 2018;19(6):1219-1226. doi: $10.1093 / \mathrm{pm} / \mathrm{pnx} 237$

70. Fishman MA, Calodney A, Kim P, et al. Prospective, multicenter feasibility study to evaluate differential target multiplexed spinal cord stimulation programming in subjects with chronic intractable back pain with or without leg Pain. Pain Pract. 2020;20(7):761-768. doi:10.1111/papr.12908

71. Tilley DM, Lietz CB, Cedeno DL, Kelley CA, Li L, Vallejo R. Proteomic modulation in the dorsal spinal cord following spinal cord stimulation therapy in an in neuropathic pain model. Neuromodulation. 2020. doi:10.1111/ner. 13103

72. Ruiz-Sauri A, Orduña-Valls JM, Blasco-Serra A, et al. Glia to neuron ratio in the posterior aspect of the human spinal cord at thoracic segments relevant to spinal cord stimulation. J Anat. 2019;235 (5):997-1006. doi:10.1111/joa.13061

73. Vallejo R, Tilley DM, Vogel L, Benyamin R. The role of glia and the immune system in the development and maintenance of neuropathic pain. Pain Pract. 2010;10(3):167-184. doi:10.1111/j.1533-2500.20 10.00367.x

74. Chapman KB, Groenen PS, Vissers KC, van Helmond N, StantonHicks MD. The pathways and processes underlying spinal transmission of low back pain: observations from dorsal root ganglion stimulation treatment. Neuromodulation. 2020. doi:10.1111/ ner. 13150

75. Chapman KB, Groenen PS, Patel KV, Vissers KC, van Helmond N. $\mathrm{T} 12$ dorsal root ganglion stimulation to treat chronic low back pain: a case series. Neuromodulation. 2020;23(2):203-212. doi:10.1111/ ner. 13047

76. Kallewaard JW, Edelbroek C, Terheggen M, Raza A, Geurts JW. A prospective study of dorsal root ganglion stimulation for non-operated discogenic low back pain. Neuromodulation. 2020;23 (2):196-202. doi:10.1111/ner.12937

77. Huygen F, Liem L, Cusack W, Kramer J. Stimulation of the L2-L3 dorsal root ganglia induces effective pain relief in the low back. Pain Pract. 2018;18(2):205-213. doi:10.1111/papr.12591

78. Weiner RL, Yeung A, Montes Garcia C, Tyler Perryman L, Speck B. Treatment of FBSS low back pain with a novel percutaneous drg wireless stimulator: pilot and feasibility Study. Pain Med. 2016;17 (10):1911-1916. doi:10.1093/pm/pnw075

79. Sivanesan E, Bicket MC, Cohen SP. Retrospective analysis of complications associated with dorsal root ganglion stimulation for pain relief in the FDA MAUDE database. Reg Anesth Pain Med. 2019;44 (1):100-106. doi:10.1136/rapm-2018-000007

80. Deer T, Pope J, Hunter C, et al. Safety analysis of dorsal root ganglion stimulation in the treatment of chronic pain. Neuromodulation. 2020;23(2):239-244. doi:10.1111/ner.12941 
81. Deckers K, De Smedt K, Mitchell B, et al. New Therapy for refractory chronic mechanical low back pain-restorative neurostimulation to activate the lumbar multifidus: one year results of a prospective multicenter clinical trial. Neuromodulation. 2018;21(1):48-55. doi:10.1111/ner.12741

82. Ranger TA, Cicuttini FM, Jensen TS, et al. Are the size and composition of the paraspinal muscles associated with low back pain? A systematic review. Spine J. 2017;17(11):1729-1748. doi:10.1016/j. spinee.2017.07.002

83. Sions JM, Crippen DC, Hicks GE, Alroumi AM, Manal TJ, Pohlig RT. Exploring neuromuscular electrical stimulation intensity effects on multifidus muscle activity in adults with chronic low back pain: an ultrasound Imaging-Informed Investigation. Clinical Medicine Insights: Arthritis and Musculoskeletal Disorders. 2019;12:1179544119849570. doi:10.1177/1179544119849570
84. Cohen S, Gilmore C, Kapural L, et al. Percutaneous peripheral nerve stimulation for pain reduction and improvements in functional outcomes in chronic low back pain. Mil Med. 2019;184(Suppl Supplement_1):537-541. doi:10.1093/milmed/usy310

\section{Publish your work in this journal}

The Journal of Pain Research is an international, peer reviewed, open access, online journal that welcomes laboratory and clinical findings in the fields of pain research and the prevention and management of pain. Original research, reviews, symposium reports, hypothesis formation and commentaries are all considered for publication. The manuscript

Submit your manuscript here: https://www.dovepress.com/journal-of-pain-research-journal management system is completely online and includes a very quick and fair peer-review system, which is all easy to use. Visit http:// www.dovepress.com/testimonials.php to read real quotes from published authors. 